\title{
Regional Comparison of Impacts from Seven Australian Coal Mine Wastewater Discharges on Downstream River Sediment Chemistry, Sydney Basin, New South Wales Australia
}

\author{
Nakia Belmer*, Ian Alexander Wright \\ School of Science and Health, Sydney, Western Sydney University, New South Wales, Australia
}

Email address:

bayern11@tpg.com.au (N. Belmer)

${ }^{*}$ Corresponding author

To cite this article:

Nakia Belmer, Ian Alexander Wright. Regional Comparison of Impacts from Seven Australian Coal Mine Wastewater Discharges on Downstream River Sediment Chemistry, Sydney Basin, New South Wales Australia. American Journal of Water Science and Engineering. Vol. 5, No. 2, 2019, pp. 37-46. doi: 10.11648/j.ajwse.20190502.11

Received: April 19, 2019; Accepted: May 29, 2019; Published: June 12, 2019

\begin{abstract}
This study investigates the accumulation of licensed and regulated coal mine wastewater pollutants from seven coal mines on each mines respective receiving waterways river sediments. Results from this study shows that the coal mine wastewater pollutants are accumulating within river sediments downstream of the coal mine wastewater inflows at varying levels often greater than the ANZECC guidelines for sediment and often above reference condition sediment concentrations. This is of great concern as these pollutants will likely continue to persist in the river sediment and eventually become legacy pollutants. Coal mine wastewater discharges in New South Wales are regulated by the New South Wales Environmental Protection Authority [NSW EPA] and environmental protection of receiving waterways is implemented through Environmental Protection Licenses. Environmental Protection Licenses set discharge limits for water quality and chemical concentrations within the coal mine waste waters. Though they do not take into account river sediment concentrations. It appears water column pollution regulation at these coal mines is in fact failing to protect the environment whilst still regulated and will continue into the future post mining, licensing and regulation. Water column regulation may well be impractical in protecting the environment as it appears that water column concentrations do not portray the overall environmental impact. It is recommended that the New South Wales Environmental Protection Authority investigate these findings and continue to improve water column pollutant limits as to alleviate the continued accumulation and magnification of the contaminants.
\end{abstract}

Keywords: Coal Mine Wastewater, River Sediment Chemistry, Pollutant Accumulation, River Sediment Contamination, Environmental Regulation, Australia

\section{Introduction}

Coal mining practices are well documented to contribute to an array of differing environmental problems including surface and or ground water pollution. Surface water pollution is a major environmental problem associated with coal mining and it occurs through the discharge of mine waters that are contaminated by various disturbances associated with mining practices [1-3]. Water pollution from coal mining occurs as large volumes of surface and groundwater are required to be removed from most underground coal mines. Without this, groundwater would flood most sections of the underground mining operation [1, 4].

Coal mine waste water will often be contaminated due to the disturbance of the local geology associated with mining activities. The exact nature of the water contamination will vary depending on local factors such as groundwater geochemistry, hydrology and mineralogy of the local strata [4]. Water pollution impacts attributed to treated coal mine waste waters discharged to surface waters often includes changes to $\mathrm{pH}$, elevated salinity, modified stream ionic 
composition and elevated heavy metals [5-10].

Aquatic ecosystems are often more highly sensitive to contamination from anthropogenic activities, especially as waterways are often used as sources of discharge for many industrial wastes [11]. River sediments are often heavily polluted from the mine wastewater discharges as the heavy metals become water soluble once oxygenated and discharged, often falling out of the water column and accumulating in river sediments often remaining indefinitely [12-17]. Heavy metal contamination within aquatic environments can persist much longer than terrestrial organic pollutants. This is due to the lack of a "biodegradation function" of heavy metals in aquatic ecosystems in comparison to a terrestrial ecosystem [18, 19].

The local geology of the study area is described as part of the sedimentary sequence deposited throughout the Sydney Basin. This sedimentary sequence comprises of many layers including the marine dominated Shoalhaven Group, the Illawarra Coal Measures, the Narrabeen and Hawkesbury Sandstone Groups, the Wianamatta Group and small pockets of Basalt flows [20-21]. The Illawarra Coal Measure Group is divided into two sub groups, the Nile sub group and the Charbon sub group. The Nile subgroup is described as having marine influences whilst the Charbon subgroup is described as being peat influenced and contains large deposits of economically important coal seams [20-21]. Minerology of most Australian Coals are said to be dominated by phosphates, carbonates, sulphides, silicates and other crystalline mineral groups [22].

There is a rich literature on coal mines and water pollution in some parts of the world, such as the United States which includes many regional studies of active and inactive mines [3, 23 and 24]. One major data gap is that there have been very few studies involving sediment chemistry [none in
Australia] comparing sediment contamination impacts from a regional group of coal mines that discharge waste waters. This relative lack of sediment contamination studies from Australian coal mines is a large scientific gap and requires intensive research. Especially when waterways sediment legacy pollution in many other settings is so well understood.

Coal mine wastewater discharges in New South Wales are regulated by the New South Wales Environmental Protection Authority [NSW EPA] and environmental protection of receiving waterways is implemented through Environmental Protection Licenses [EPL's], under the Protection of the Environment Operations Act 1997 [POEO Act]. EPL's set discharge limits for water quality and chemical properties in which coal mine waste waters that are discharged to the environment must adhere to the studies [6 and 7].

We hypothesize that the heavy metal contamination of the water column is subsequently bioaccumulating and magnifying within the river sediments.

\section{Methods}

\subsection{Study Sites}

This study investigates river sediments from waterways receiving wastewater from seven coal mines in the Sydney Basin. Four are located within the Greater Blue Mountains area. They are Angus Place, Canyon, Clarence and Springvale Collieries. Three mines are located in the Greater Southern Highlands area, those being Berrima [Medway], Tahmoor and Westcliff Collieries [Figure 1]. The geology of all mine locations share many similarities as they all extract coal from various seams within the Illawarra coal measures spanning the southern and western coalfields within the greater Sydney Basin [20, 21 and 22].

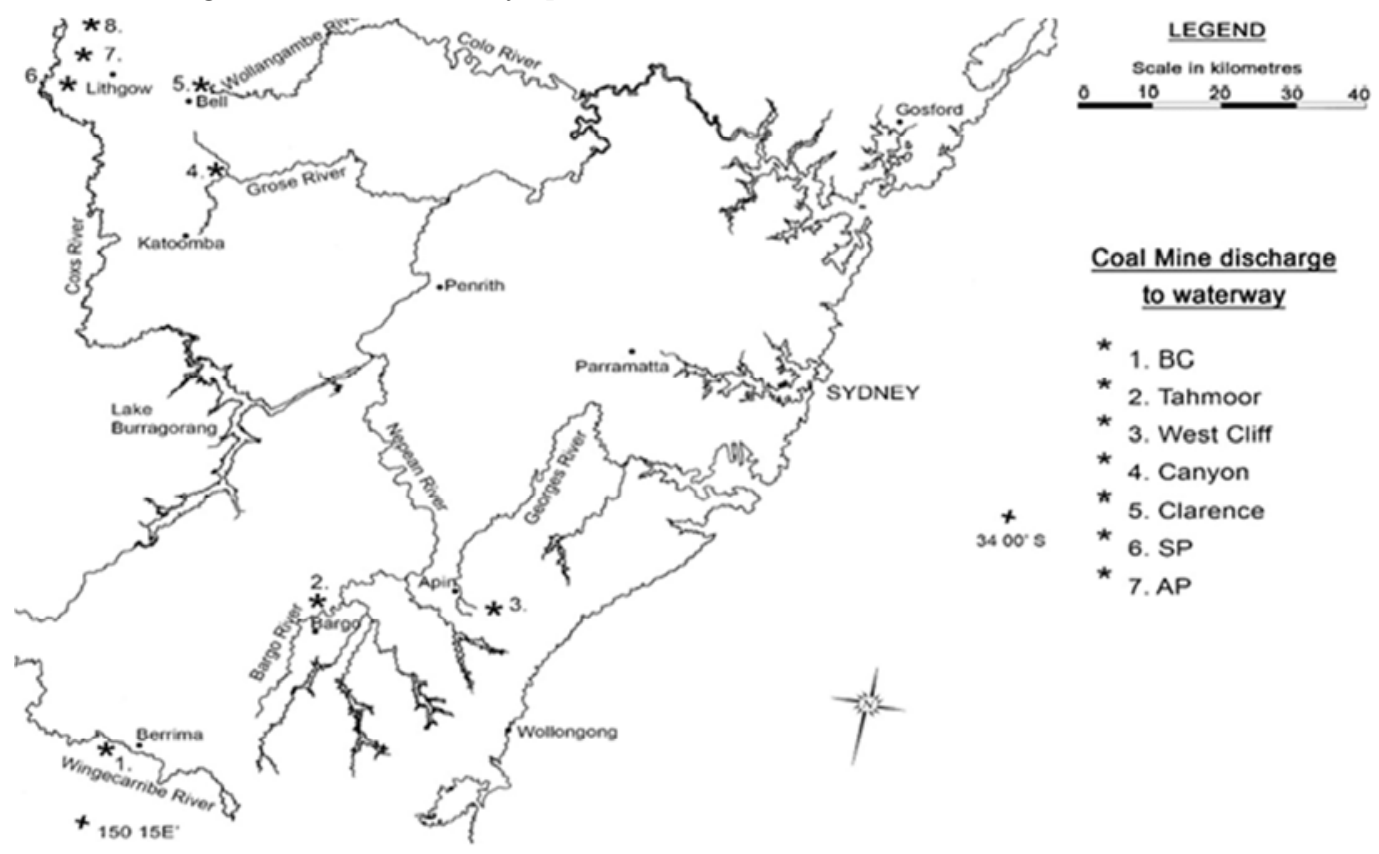

Figure 1. Map of lower Sydney basin, its major waterways and location of the seven coal mines [marked by * and numbered] used in this study. [1 Berrima Colliery, 2. Tahmoor Colliery, 3. West Cliff Colliery, 4. Canyon Colliery, 5. Clarence Colliery, 6. Springvale Colliery, 7. Angus Place Colliery]. Some of the smaller tributaries that receive mine waste are not shown [Kangaroo Ck, Sawyers Swamp, Springvale Ck, Dalpura Ck]. 


\subsection{Sediment Sampling}

Sediment samples were collected on one occasion from upstream and downstream of each coal mines wastewater inflow other than for Angus Place Colliery [Kangaroo Creek]. This was due to no upstream location being available. A nearby naturally dilute reference stream was used as its paired upstream sample location [Cox's River]. This was achieved by sampling river sediments in a zone of accumulated sediment, following standard methods recommended by the Victorian EPA [25]. Samples were placed into sealed glass sampling jars supplied by a commercial laboratory and stored. Three replicated samples were collected and analysed using standard methods [APHA 1998] by Envirolab [Chatswood, NSW] a National Associations of Testing Authorities accredited laboratory for the following pollutants [Barium, Cobalt, Copper, Lithium, Manganese, Nickel, Strontium and Zinc.].

\subsection{Data Analysis and Guideline Comparison}

For univariate data analysis Students t-test were used to test for differences in river sediment chemistry between samples upstream versus downstream of each mine waste inflows. Results are also compared to Australian sediment guidelines [ANZECC 2000 guideline values for toxicants in sediment] where available [Copper, Nickel and Zinc] and also two international sediment quality guideline values, including a threshold effect concentration [TEC] and a probable effect concentration [PEC] where available [Nickel and Zinc] [26]. The remaining pollutants which do not have Australian or international guidelines were compared discussed within relation to upstream [reference] sediment values.

\section{Results}

Barium recorded statistically significant differences between upstream and downstream samples for all mines other than Westcliff Colliery when analysed through Students t-Test [table 1]. The ANZECC 2000 guidelines do not stipulate load limits for Barium in sediment. Reference barium at Sawyers Swamp upstream of Angus Place and Springvale Collieries waste water sources recorded a mean of $10.3 \mathrm{mg} / \mathrm{kg}$ whilst downstream barium concentrations were mean $163.3 \mathrm{mg} / \mathrm{kg}$ an increase over 15 times. Barium at Cox's River [reference] site was mean $56 \mathrm{mg} / \mathrm{kg}$ whilst Kangaroo Creek below Angus Place Collieries wastewater inflow recorded a mean of $173.3 \mathrm{mg} / \mathrm{kg}$ an increase greater than three times.

Springvale Creek barium increased over four times from an upstream mean of $115.7 \mathrm{mg} / \mathrm{kg}$ to a mean of $490 \mathrm{mg} / \mathrm{kg}$ below the coal mine waste water discharge. Dalpura Creek reference recorded the lowest barium of this study with a mean of $1.33 \mathrm{mg} / \mathrm{kg}$ increasing to $2.8 \mathrm{mg} / \mathrm{kg}$ downstream. Wollangambe river also recorded low reference barium of 3.0 $\mathrm{mg} / \mathrm{kg}$ upstream increasing eight times to $25 \mathrm{mg} / \mathrm{kg}$ below the discharge. The Wingecarribee River above Berrima [Medway] Collieries wastewater discharge recorded a mean of $41.4 \mathrm{mg} / \mathrm{kg}$ increasing over 16 times to a mean of 685 $\mathrm{m} / \mathrm{kg}$. The Bargo River reference site recorded low barium concentrations of $5.5 \mathrm{mg} / \mathrm{kg}$ similar to Dalpura Creek and the Wollanganbe River. This increased nearly ten times to a mean of $54.5 \mathrm{mg} / \mathrm{kg}$ below Tahmoor Collieries wastewater discharge [table 1 and figure 2].

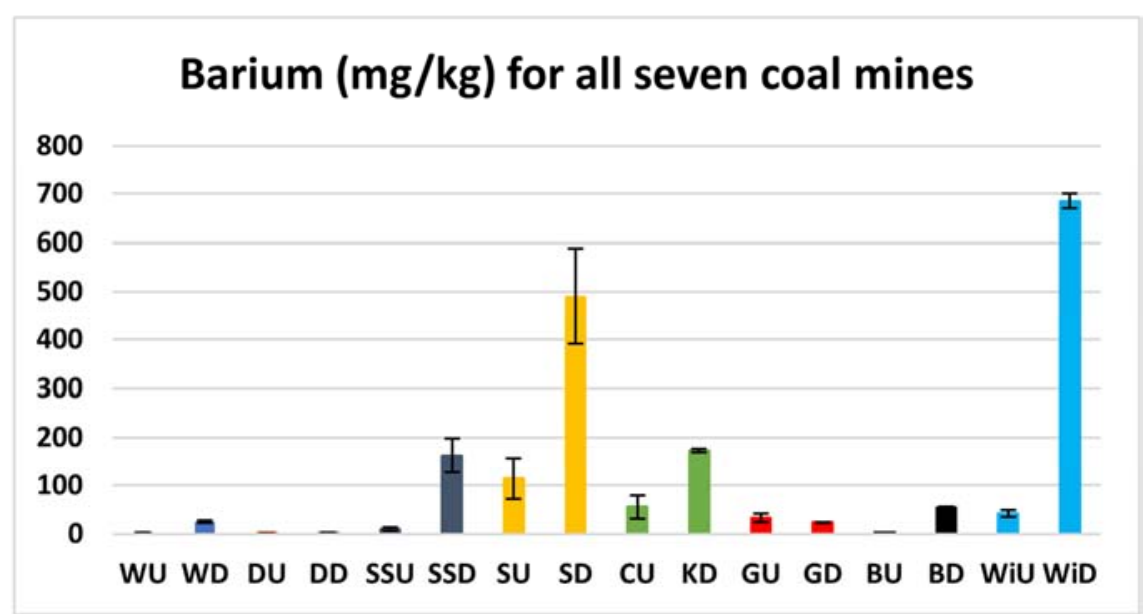

Figure 2. Barium for all seven mines with standard error bars. $U=$ upstream, $D=$ downstream, $W=$ Wollangambe $D=$ Dalpura, SS $=$ Sawyers Swamp, $S=$ Springvale, $C=$ Cox's, $K=$ Kangaroo, $G=$ Georges, $B=$ Bargo and Wi $=$ Wingecarribee.

Cobalt was found to be statistically significantly different for Sawyers Swamp, Cox's River/Kangaroo Creek, Dalpura Creek, the Wollangambe River and the Wingecarribee River between upstream and downstream sample locations when analysed with Students T-test [table 1]. There is no ANZECC 2000 guideline for cobalt in sediment. Sawyers Swamp increased from $0.67 \mathrm{mg} / \mathrm{kg}$ to $88.5 \mathrm{mg} / \mathrm{kg}$ over 100 times higher. Dalpura Creek was below laboratory detection limits upstream of the closed Canyon Coal mines water discharge whilst a mean of $2.1 \mathrm{mg} / \mathrm{kg}$ was recorded downstream. The Wollangambe River also recorded below laboratory detectable limits whilst in comparison downstream mean 
cobalt was $226.7 \mathrm{mg} / \mathrm{kg}$. The greatest concentration in cobalt in sediment was recorded at the Wingecarribee River with upstream reference cobalt measuring a mean of $69.4 \mathrm{mg} / \mathrm{kg}$ increasing nearly 80 times downstream of Berrima [Medway] Collieries wastewater inflow to $695 \mathrm{mg} / \mathrm{kg}$. Cox's/Kangaroo
Creek recorded cobalt in sediment concentrations upstream of mean $4.8 \mathrm{mg} / \mathrm{kg}$ in contrast to Kangaroo Creek downstream of Angus Place Colliery which recorded a mean of $18 \mathrm{mg} / \mathrm{kg}$ [table 1 and figure 3].

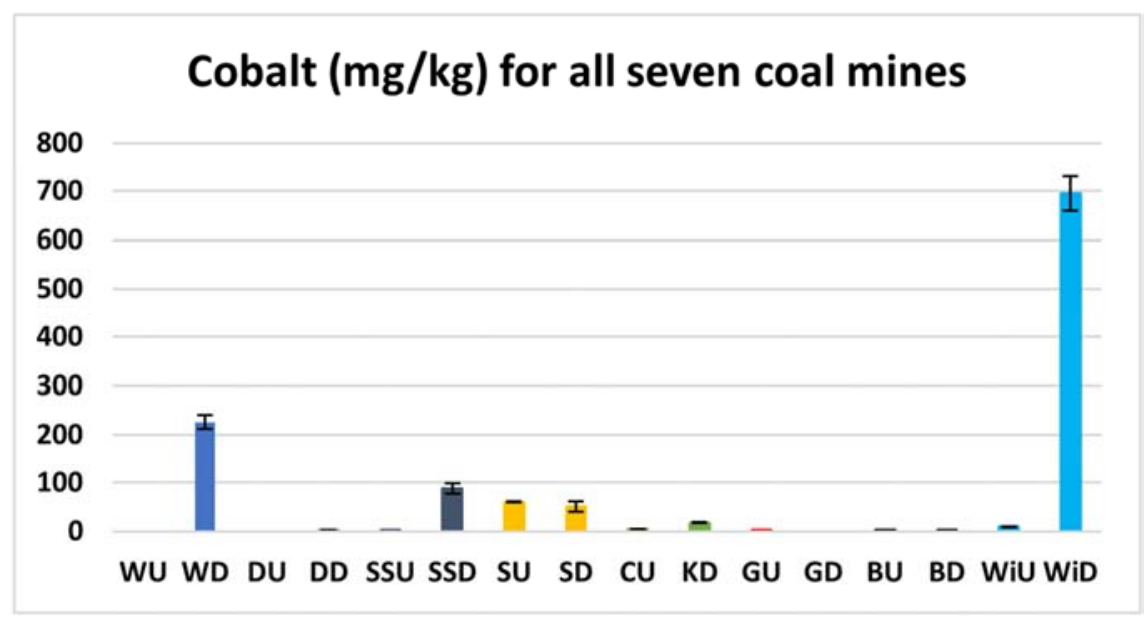

Figure 3. Cobalt for all seven mines with standard error bars. $U=$ upstream, $D=$ downstream, $W=$ Wollangambe $D=$ Dalpura, SS $=$ Sawyers $S w a m p, S=$ Springvale, $C=$ Cox's, $K=$ Kangaroo, $G=$ Georges, $B=$ Bargo and Wi $=$ Wingecarribee.

Copper was found to be statistically significantly different for Sawyers Swamp, Cox's River/Kangaroo Creek, the Wollangambe River, the Wingecarribee River and the Georges River when analysed with Students T-test between upstream and downstream sample locations [table 1]. The ANZECC 2000 ISQG-Low guideline for copper in sediment is $65 \mathrm{mg} / \mathrm{kg}$ which is above the findings of this study. One sample stream, the Georges River recorded a decrease in copper concentrations in sediment. The Georges River recorded mean copper upstream of Westcliff Collieries waste water inflow of $3.5 \mathrm{mg} / \mathrm{kg}$ decreasing to $1 \mathrm{mg} / \mathrm{kg}$ downstream. Sawyers Swamp increased over 10 times from
$1.17 \mathrm{mg} / \mathrm{kg}$ upstream to $14 \mathrm{mg} / \mathrm{kg}$ downstream. Kangaroo Creek below Angus Place Collieries wastewater discharge was $10.1 \mathrm{mg} / \mathrm{kg}$ higher [mean $17.3 \mathrm{mg} / \mathrm{kg}$ ] than the reference stream Cox's River which had mean copper concentrations in sediment of $7.2 \mathrm{mg} / \mathrm{kg}$. The Wollangambe River upstream of Clarence Collieries waste water discharge recorded mean copper of $0.67 \mathrm{mg} / \mathrm{kg}$ in sediment increasing to $2 \mathrm{mg} / \mathrm{kg}$ downstream. Berrima [Medway] Collieries wastewater discharge was seen to increase copper in the Wingecarribee Rivers sediments from $3.8 \mathrm{mg} / \mathrm{kg}$ upstream to a mean of 13.5 $\mathrm{mg} / \mathrm{kg}$ downstream [table 1 and figure 4 ].

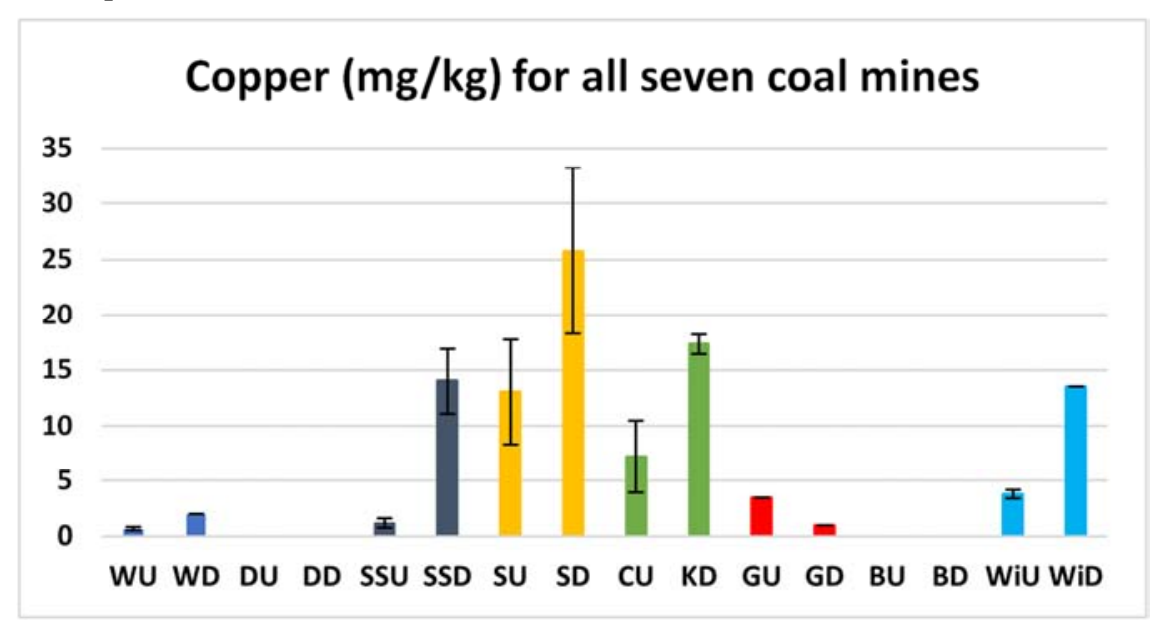

Figure 4. Copper for all seven mines with standard error bars. $U=$ upstream, $D=$ downstream, $W=$ Wollangambe $D=$ Dalpura, SS $=$ Sawyers $S w a m p, S=$ Springvale, $C=$ Cox's, $K=$ Kangaroo, $G=$ Georges, $B=$ Bargo and Wi $=$ Wingecarribee.

Lithium upstream when compared to downstream was seen to be statistically significantly different when analysed with Students T-test for Sawyers Swamp, Springvale Creek, Cox's River/ Kangaroo Creek, the Wollangambe River and the Bargo River [table 1]. There is no ANZECC 2000 ISQG-Low guideline for lithium in sediment. All downstream sample locations recorded increases in Lithium other than Dalpura Creek which recorded below laboratory detection limits for both its upstream and downstream sample locations. Lithium concentrations in sediment were found to be below laboratory detectable limits at Sawyers 
Swamp upstream whilst recording a mean of $29.6 \mathrm{mg} / \mathrm{kg}$ downstream of Angus Place and Springvale Collieries. Kangaroo Creek below Angus Place Colliery recorded mean lithium of 13.3 $\mathrm{mg} / \mathrm{kg}$ in comparison Cox; s Creek upstream recorded below detectable lithium concentrations. The Wollangambe River upstream also recorded below detectable limits of lithium in sediment whilst downstream mean lithium was $3.67 \mathrm{mg} / \mathrm{kg}$. Springvale Creek lithium was found to have a mean of 1.83 $\mathrm{mg} / \mathrm{kg}$ increasing to $7.75 \mathrm{mg} / \mathrm{kg}$ below Springvale Collieries waste water inflow. The Bargo River increased from below detectable limits of lithium to $35 \mathrm{mg} / \mathrm{kg}$ downstream of Tahmoor Collieries wastewater discharge [Table 1 and Figure 5].

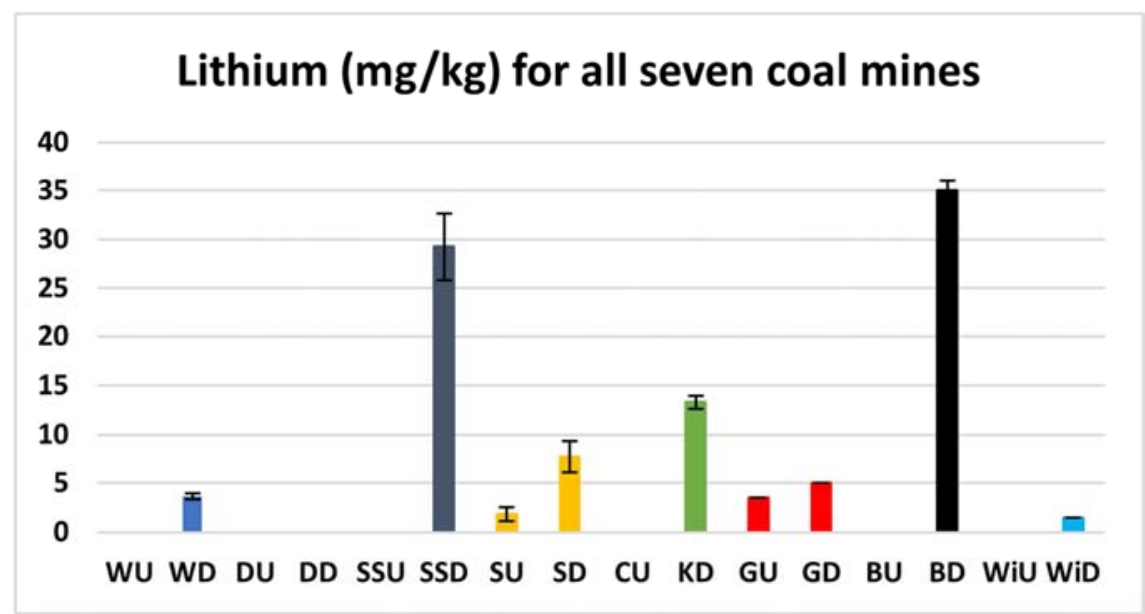

Figure 5. Lithium for all seven mines with standard error bars. $U=$ upstream, $D=$ downstream, $W=$ Wollangambe $D=D a l p u r a, S S=S a w y e r s ~ S w a m p, ~ S=$ Springvale, $C=$ Cox's, $K=$ Kangaroo, $G=$ Georges, $B=$ Bargo and Wi $=$ Wingecarribee.

Manganese at all sample locations other than the Bargo River and the Georges River recorded statistically significant differences when analysed with Students T-test between upstream and downstream samples [table 1]. There is no ANZECC 2000 ISQG-Low guideline for manganese in sediment. Sawyers Swamp upstream was found to have a mean of $15 \mathrm{mg} / \mathrm{kg}$ of manganese whilst downstream manganese increased to $2425 \mathrm{mg} / \mathrm{kg}$ an increase over 160 times, the greatest increase in manganese at all sample locations. Springvale Creek increased from a mean of $416.7 \mathrm{mg} / \mathrm{kg}$ upstream of Springvale Collieries waste water discharge to $13300 \mathrm{mg} / \mathrm{kg}$ over 30 times higher than reference manganese. Kangaroo Creek below Angus Place Collieries wastewater inflow measured mean manganese of $2233.3 \mathrm{mg} / \mathrm{kg}$ whilst its paired reference stream was [mean $90.2 \mathrm{mg} / \mathrm{kg}$ ]. Dalpura Creek upstream of the Canyon Colliery discharge was below laboratory detection limits in comparison downstream was $20.6 \mathrm{mg} / \mathrm{kg}$. The Wollangambe River downstream of Clarence Collieries wastewater inflow recorded mean manganese in sediment of $6520 \mathrm{mg} / \mathrm{kg}$ whilst upstream manganese was $48.7 \mathrm{mg} / \mathrm{kg}$ this is an increase downstream over 120 the second highest increase recorded for manganese [table 1 and figure 6].

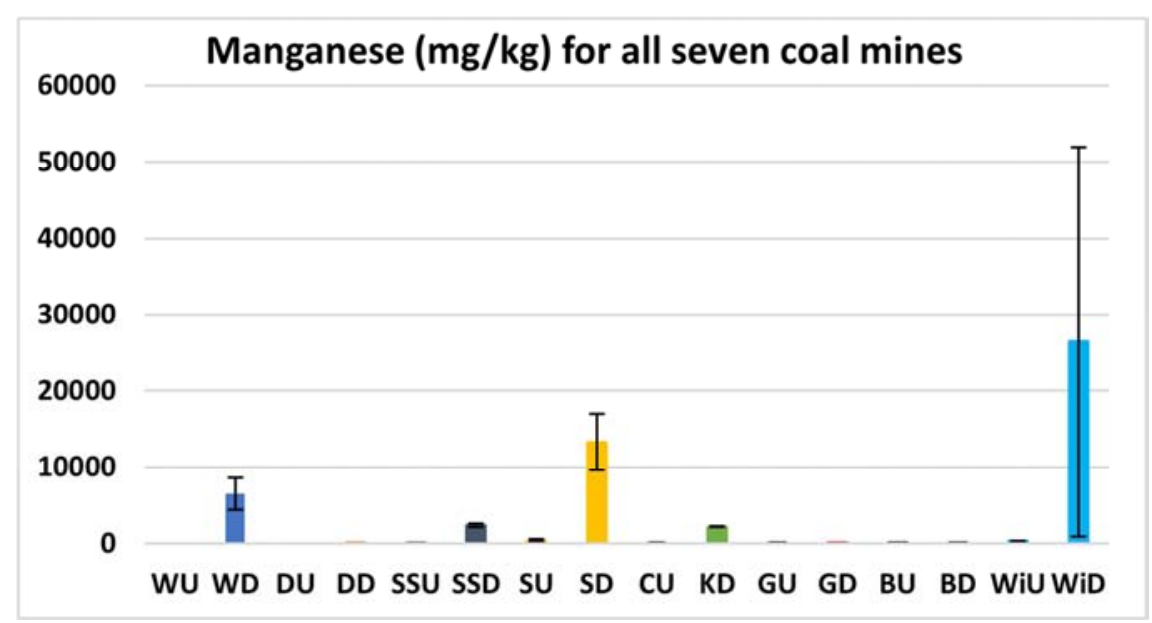

Figure 6. Manganese for all seven mines with standard error bars. $U=$ upstream, $D=$ downstream, $W=$ Wollangambe $D=$ Dalpura, SS $=$ Sawyers Swamp, $S$ = Springvale, $C=$ Cox's, $K=$ Kangaroo, $G=$ Georges, $B=$ Bargo and Wi $=$ Wingecarribee.

Nickel in sediment recorded statistically significant differences between upstream and downstream sample locations for all sites other that Bargo and Georges Rivers [table 1]. The ANZECC 2000 ISQG-Low guideline for nickel in sediment is $21 \mathrm{mg} / \mathrm{kg}$. Both Dalpura Creek and the
Wollangambe River recorded reference upstream nickel concentrations below laboratory detection limits increasing downstream to $6 \mathrm{mg} / \mathrm{kg}$ and $180 \mathrm{mg} / \mathrm{kg}$ respectively. Sawyers Swamp increased some 140 times from $0.83 \mathrm{mg} / \mathrm{kg}$ upstream to $114 \mathrm{mg} / \mathrm{kg}$ downstream. Springvale Creek increased from 
a mean of $18.7 \mathrm{mg} / \mathrm{kg}$ to a mean downstream of $60.6 \mathrm{mg} / \mathrm{kg}$. Cox's River recorded mean nickel in sediment of $4.4 \mathrm{mg} / \mathrm{kg}$ in contrast its paired impact stream Kangaroo Creek below Angus Place Collieries wastewater discharge was [mean 17.7 $\mathrm{mg} / \mathrm{kg}$ ]. The Wingecarribee River recorded upstream mean nickel of $11 \mathrm{mg} / \mathrm{kg}$ whilst downstream a mean of $1030 \mathrm{mg} / \mathrm{kg}$ was recorded nearly 95 times higher. This study reveals that the Wollangambe River downstream [10 times higher], Sawyers Swamp downstream [over 5 times higher], Springvale Creek downstream [near 3 times higher] and the Wingecarribee River downstream [nearly 50 times higher] all have mean nickel well above the recommended ANZECC guideline [table 1 and figure 7].

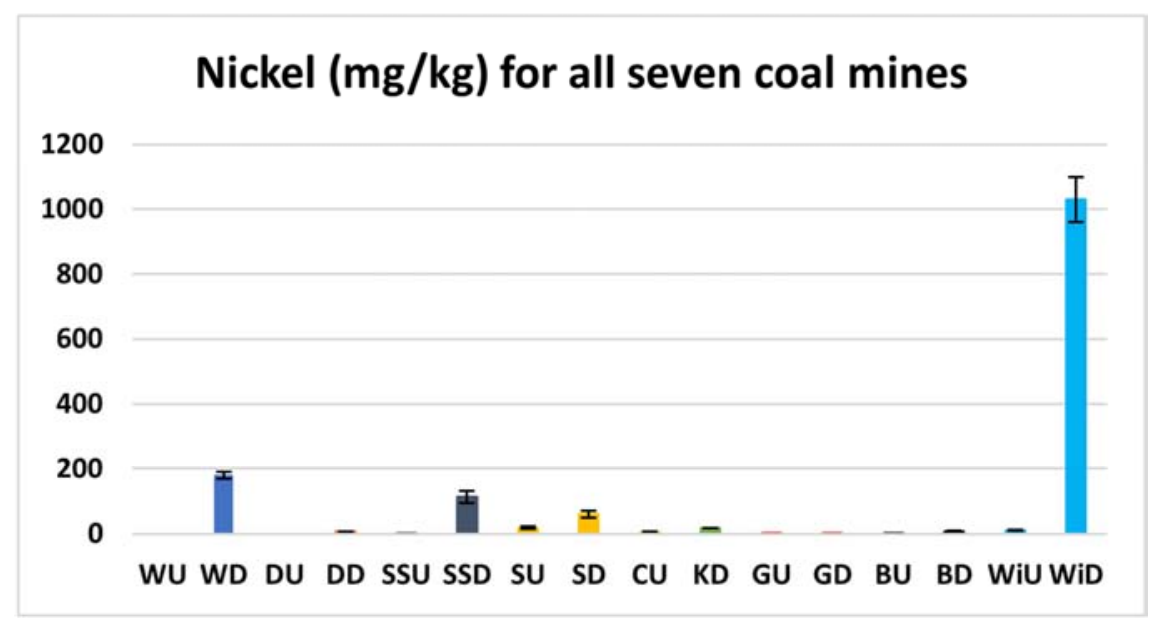

Figure 7. Nickel for all seven mines with standard error bars. $U=$ upstream, $D=$ downstream, $W=$ Wollangambe $D=$ Dalpura, SS $=$ Sawyers Swamp, $S=$ Springvale, $C=$ Cox's, $K=$ Kangaroo, $G=$ Georges, $B=$ Bargo and Wi $=$ Wingecarribee. The ANZECC $2000 I S Q G$-Low guideline for nickel in sediment $[21$ $m g / k g]$.

Strontium was found to be statistically significantly different when analysed with Students T-test between upstream and downstream for all sample streams other than the Georges River and Dalpura Creek. Dalpura Creek measured below detectable laboratory limits of strontium at both upstream and downstream sample locations [table 1]. There is no ANZECC 2000 ISQG-Low guideline for strontium in sediment. Sawyers Swamp increased 10 times downstream from a mean of 1.67 $\mathrm{mg} / \mathrm{kg}$ to a mean of $16.6 \mathrm{mg} / \mathrm{kg}$. Springvale Creek upstream recorded a mean of $11 \mathrm{mg} / \mathrm{kg}$ increasing over three times to a mean of $36.5 \mathrm{mg} / \mathrm{kg}$ downstream of Springvale Collieries waste water discharge. Cox's River recorded mean reference strontium of $6.2 \mathrm{mg} / \mathrm{kg}$ whilst its paired downstream site Kangaroo Creek recorded a mean of $41.3 \mathrm{mg} / \mathrm{kg}$ an increase over six times. The Wollangambe River upstream of Clarence Collieries waste water discharge recorded mean strontium in sediment of $0.67 \mathrm{mg} / \mathrm{kg}$ increasing slightly to $1.33 \mathrm{mg} / \mathrm{kg}$ downstream. The Wingecarribee River upstream of Berrima [Medway] Collieries waste adit recorded mean strontium of $9.4 \mathrm{mg} / \mathrm{kg}$ increasing over 6 times to $59 \mathrm{mg} / \mathrm{kg}$ downstream. The greatest increase was recorded on the Bargo River with mean strontium downstream of Tahmoor Collieries wastewater inflow recorded at $25.5 \mathrm{mg} / \mathrm{kg}$ an increase over 25 times from reference conditions [mean $0.88 \mathrm{mg} / \mathrm{kg}$ ] [table 1 and figure 8 ].

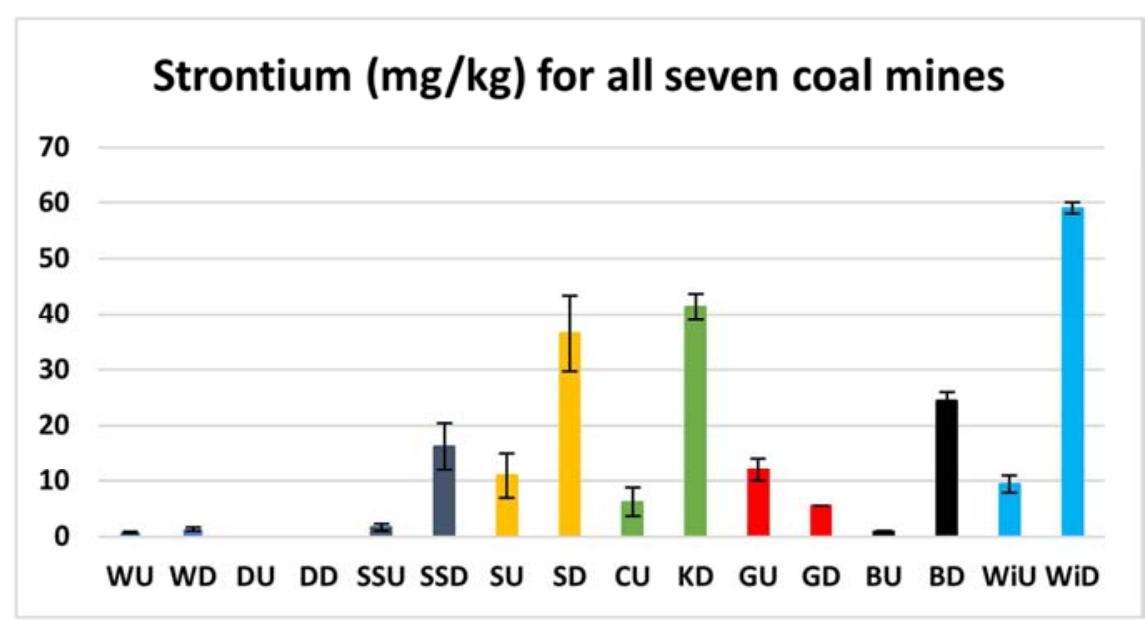

Figure 8. Strontium for all seven mines with standard error bars. $U=$ upstream, $D=$ downstream, $W=$ Wollangambe $D=$ Dalpura, SS $=$ Sawyers $S w a m p, S=$ Springvale, $C=$ Cox's, $K=$ Kangaroo, $G=$ Georges, $B=$ Bargo and Wi $=$ Wingecarribee.

Statistically significant differences were found for zinc when analysed with Students T-test between upstream and downstream samples for all sample streams other than the Bargo River [table 1]. The ANZECC 2000 ISQG-Low 
guideline for zinc in sediment is $200 \mathrm{mg} / \mathrm{kg}$. Sawyers Swamp mean zinc upstream was recorded as $7.33 \mathrm{mg} / \mathrm{kg}$ increasing Over 50 times downstream to a mean of $272.5 \mathrm{mg} / \mathrm{kg}$. Springvale Creek recorded the highest upstream zinc concentrations of $87 \mathrm{mg} / \mathrm{kg}$ thought this still increased downstream of Springvale Collieries waste water inflow some four times to a mean of $350 \mathrm{mg} / \mathrm{kg}$. Cox's River reference stream measured a mean of $34.6 \mathrm{mg} / \mathrm{kg}$ whilst its paired downstream sample recorded mean zinc of $710 \mathrm{mg} / \mathrm{kg}$ below Angus Place Collieries waste water discharge. Dalpura Creek zinc concentrations in sediment were below laboratory detectable limits upstream of Canyon Collieries waste water discharge whilst downstream recorded a mean of $19.6 \mathrm{mg} / \mathrm{kg}$. The Wollangambe River saw an increase over 80 times from reference [upstream] zinc measuring a mean of $3 \mathrm{mg} / \mathrm{kg}$ whilst in comparison downstream of Clarence Collieries wastewater inflow zinc was recorded at a mean of 243.3 $\mathrm{mg} / \mathrm{kg}$. The Wingecarribee River recorded the greatest concentrations and increase of this study. Upstream of Berrima [Medway] Collieries wastewater discharge zinc in sediment was recorded at a mean of $31.2 \mathrm{mg} / \mathrm{kg}$ increasing nearly 190 times to a mean of $5950 \mathrm{mg} / \mathrm{kg}$ below Berrima [Medway] Collieries wastewater adit.

The Georges River in contrast recorded much higher zinc concentrations in sediment upstream [mean $42 \mathrm{mg} / \mathrm{kg}$ ] than downstream which measured a mean of $5.5 \mathrm{mg} / \mathrm{kg}$. This study reveals that the Wollangambe River downstream [43 $\mathrm{mg} / \mathrm{kg}$ higher], Sawyers Swamp downstream [72 mg/kg higher], Springvale Creek downstream [150 mg/kg higher], Kangaroo Creek downstream [500 mg/kg higher] and the Wingecarribee River downstream [5750 mg/kg higher] zinc in sediment results are above the recommended ANZECC guideline to varying magnifications [table 1 and figure 9]. Similar results were reported by Pavlowsky et al in the Big River area of the Ozark Highlands Southern Missouri North America. This study investigated sediment legacy pollutants from closed lead mining activities and revealed mean Zinc concentrations of $502 \mathrm{mg} / \mathrm{kg}$ ranging between 83 and 1554 $\mathrm{mg} / \mathrm{kg}$. This is similar to this study other than downstream of the Berrima [Medway] Colliery.

Table 1. Sediment chemistry results for each coal mine. Mean values and p values. BD = Below Laboratory Detection Limits. $n / s=n o t$ significant. Red font is concentrations above the ANZECC Guideline [28].

\begin{tabular}{|c|c|c|c|c|c|c|c|c|}
\hline $\begin{array}{l}\text { Colliery name, } p \text { value, sample } \\
\text { river and location/ Parameter }\end{array}$ & Barium & Cobalt & Copper & Lithium & Manganese & Nickel & Strontium & Zinc \\
\hline \multicolumn{9}{|l|}{ Springvale and Angus Place } \\
\hline $\mathrm{p}$ value & 0.01 & 0.002 & 0.01 & 0.002 & 0.0006 & 0.004 & 0.02 & 0.003 \\
\hline Sawyers upstream & 10.3 & 0.67 & 1.17 & $\mathrm{BD}$ & 15 & 0.83 & 1.67 & 7.33 \\
\hline Sawyers downstream & 163.3 & 88.5 & 14 & 29.6 & 2425 & 114 & 16.6 & 272.5 \\
\hline \multicolumn{9}{|l|}{ Springvale } \\
\hline $\mathrm{p}$ value & 0.01 & 0.23 & 0.1 & 0.02 & 0.02 & 0.01 & 0.01 & 0.02 \\
\hline Springvale upstream & 115.7 & 60.7 & 13 & 1.83 & 416.7 & 18.7 & 11 & 87 \\
\hline Springvale downstream & 490 & 51.5 & 25.6 & 7.75 & 13300 & 60.6 & 36.5 & 350 \\
\hline \multicolumn{9}{|l|}{ Angus Place } \\
\hline $\mathrm{p}$ value & 0.004 & 0.003 & 0.01 & 0.001 & 0.0001 & 0.0007 & $2.54 \mathrm{E}-05$ & 0.0002 \\
\hline Cox's upstream & 56 & 4.8 & 7.2 & $\mathrm{BD}$ & 90.2 & 4.4 & 6.2 & 34.6 \\
\hline Kangaroo downstream & 173.3 & 18 & 17.3 & 13.3 & 2233.3 & 17.7 & 41.3 & 710 \\
\hline \multicolumn{9}{|l|}{ Canyon } \\
\hline $\mathrm{p}$ value & 0.02 & 0.03 & $\mathrm{n} / \mathrm{a}$ & $\mathrm{n} / \mathrm{a}$ & 0.01 & 0.0003 & $\mathrm{n} / \mathrm{a}$ & 0.0001 \\
\hline Dalpura upstream & 1.33 & $\mathrm{BD}$ & $\mathrm{BD}$ & $\mathrm{BD}$ & $\mathrm{BD}$ & $\mathrm{BD}$ & $\mathrm{BD}$ & $\mathrm{BD}$ \\
\hline Dalpura downstream & 2.8 & 2.1 & $\mathrm{BD}$ & $\mathrm{BD}$ & 20.6 & 6 & $\mathrm{BD}$ & 19.6 \\
\hline \multicolumn{9}{|l|}{ Clarence } \\
\hline $\mathrm{p}$ value & 0.007 & 0.03 & 0.01 & 0.03 & $3.64 \mathrm{E}-06$ & 0.03 & 0.006 & 0.003 \\
\hline Wollangambe upstream & 3 & $\mathrm{BD}$ & 0.67 & $\mathrm{BD}$ & 48.7 & $\mathrm{BD}$ & 0.67 & 3 \\
\hline Wollangambe downstream & 25 & 226.7 & 2 & 3.67 & 6520 & 180 & 1.33 & 243.3 \\
\hline \multicolumn{9}{|l|}{ Berrima [Medway] } \\
\hline $\mathrm{p}$ value & 0.008 & 0.02 & 0.002 & 0.15 & 0.25 & 0.02 & $5.98 \mathrm{E}-07$ & 0.003 \\
\hline Wingecarribee upstream & 41.4 & 9.4 & 3.8 & $\mathrm{BD}$ & 342 & 11 & 9.4 & 31.2 \\
\hline Wingecarribee downstream & 685 & 695 & 13.5 & 1.5 & 26475 & 1030 & 59 & 5950 \\
\hline \multicolumn{9}{|l|}{ Tahmoor } \\
\hline $\mathrm{p}$ value & 0.01 & 0.36 & $\mathrm{n} / \mathrm{a}$ & 0.009 & 0.07 & 0.14 & 0.02 & 0.25 \\
\hline Bargo upstream & 5.5 & 1.5 & $\mathrm{BD}$ & $\mathrm{BD}$ & 80 & 1 & 0.88 & 6 \\
\hline Bargo downstream & 54.5 & 2 & $\mathrm{BD}$ & 35 & 25.5 & 6.5 & 24.5 & 9.5 \\
\hline \multicolumn{9}{|l|}{ Westcliff } \\
\hline $\mathrm{p}$ value & 0.23 & 0.25 & 0.06 & 0.1 & 0.07 & 0.09 & 0.1 & 0.04 \\
\hline Georges upstream & 33.5 & 0.75 & 3.5 & 3.5 & 130 & 1 & 12 & 42 \\
\hline Georges downstream & 24 & $\mathrm{BD}$ & 1 & 5 & 36.5 & 0.75 & 5.5 & 5.5 \\
\hline
\end{tabular}




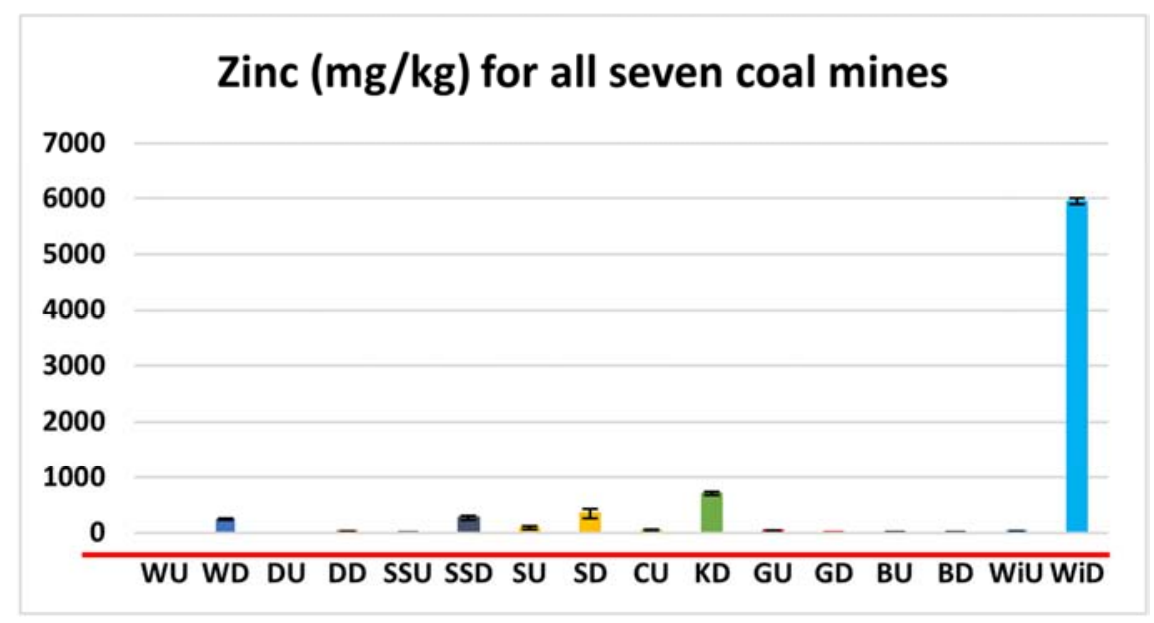

Figure 9. Zinc for all seven mines with standard error bars. $U=$ upstream, $D=$ downstream, $W=$ Wollangambe $D=D a l p u r a, S S=$ Sawyers Swamp, $S=$ Springvale, $C=$ Cox's, $K=$ Kangaroo, $G=$ Georges, $B=$ Bargo and Wi $=$ Wingecarribee. The ANZECC 2000 ISQG-Low guideline for nickel in sediment $[200$ $m g / k g]$.

\section{Discussion}

For the three parameters measured in this study [Copper, Nickel and Zinc] which have Australian sediment guidelines [ANZECC 2000 guidelines for toxicants] increased to varying degrees downstream of almost all the mines. Copper recorded increases in downstream sediment concentrations below four of the eight discharges excluding Canyon, Tahmoor and Westcliff collieries ranging from double and ten times the recorded upstream [reference] sediment loads. Although all the downstream samples were below the Australian guidelines such large increases from reference conditions are of concern. Nickel was found to increase in downstream sediments below seven of the eight waste water inflows from 3 times to 180 times the reference sediment concentrations. Four of the downstream sediment sample concentrations were above the Australian sediment guidelines for nickel in sediment $[21 \mathrm{mg} / \mathrm{kg}]$ as for both international sediment guidelines TEL $[16 \mathrm{mg} / \mathrm{kg}]$ and PEL $43 \mathrm{mg} / \mathrm{kg}$ ].

Of most concern is Berrima [Medway] Colliery which recorded an increase from $11 \mathrm{mg} / \mathrm{kg}$ upstream [half of the Australian guideline] to $1030 \mathrm{mg} / \mathrm{kg}$ downstream [nearly 50 times the Australian guideline]. Clarence Colliery which recorded below laboratory detectable limits upstream $[<0.5$ $\mathrm{mg} / \mathrm{kg}$ ] increasing to $180 \mathrm{mg} / \mathrm{kg}$ downstream [over 7 times the Australian guideline]. The combined discharge point from Springvale and Angus Place collieries increased concentrations from $0.83 \mathrm{mg} / \mathrm{kg}$ upstream to $114 \mathrm{mg} / \mathrm{kg}$ downstream [over 5 times the Australian guideline] whilst the individual discharge from Springvale Colliery recorded $18.7 \mathrm{mg} / \mathrm{kg}$ upstream increasing to $60.6 \mathrm{mg} / \mathrm{kg}$ downstream nearly three times the Australian guideline.

Zinc is also of major concern at many of the coal mines with large increases measured downstream of six of the eight discharges. Zinc increased downstream of the six coal mines between 6 times and 185 times that of reference sediment concentrations with five of the six recording values above the recommended Australian sediment guidelines $[200 \mathrm{mg} / \mathrm{kg}$ ] and one of the international sediment guideline values TEL $[123 \mathrm{mg} / \mathrm{kg}]$ whilst three of the five were above the PEL international guideline of $315 \mathrm{mg} / \mathrm{kg}$. Berrima [Medway] Colliery recorded the greatest increase from $31.2 \mathrm{mg} / \mathrm{kg}$ upstream increasing to $5950 \mathrm{mg} / \mathrm{kg}$ [nearly 30 times the Australian guideline] along with Angus Place Colliery with increased sediment loads from reference conditions [34.6 $\mathrm{mg} / \mathrm{kg}$ ] increasing downstream to $710 \mathrm{mg} / \mathrm{kg}$ [3 and a half times the Australian guideline]. Sediment concentration downstream of Springvale Colliery recorded increased zinc concentrations from $87 \mathrm{mg} / \mathrm{kg}$ to $350 \mathrm{mg} / \mathrm{kg}$. In contrast, downstream of both Clarence Colliery and the combined discharges from Angus Place and Springvale Collieries recorded concentrations just above the Australian and one international guideline [TEL] but still well above that of reference zinc in sediment [Clarence upstream $3 \mathrm{mg} / \mathrm{kg}$ increasing to $243.3 \mathrm{mg} / \mathrm{kg}$ and Angus Place/Springvale increasing from $7.33 \mathrm{mg} / \mathrm{kg}$ upstream to $272.5 \mathrm{mg} / \mathrm{kg}$ downstream.

Although five of the eight parameters discussed in this research do not have stipulated Australian guideline values [ANZECC 2000] for load limits in sediment the majority of the five parameters increased drastically within sediments below most coal mine wastewater inflows. Barium downstream of Springvale, Angus Place, Berrima [Medway] and Tahmoor collieries increased from 3 times to 16 times from that of reference conditions with Berrima [Medway] Colliery and Springvale and Angus Place's combined discharge of greatest concern increasing from 15 and 16 times respectively. Cobalt followed a similar trend with Springvale and Angus Place's combined discharge, Clarence and Berrima [Medway] collieries being of most concern. Sediment downstream of the collieries recorded increased concentrations between 60 and 440 times the that of cobalt recorded in reference sediment. Springvale and Angus Place collieries combined discharge increased Cobalt sediment concentration from $0.67 \mathrm{mg} / \mathrm{kg}$ upstream to $88.5 \mathrm{mg} / \mathrm{kg}$ downstream. Of most concern is Clarence Colliery [increasing from below laboratory detectable limits $[<0.5$ 
$\mathrm{mg} / \mathrm{kg}$ ] to $226.7 \mathrm{mg} / \mathrm{kg}$ downstream] and Berrima [Medway] Colliery increasing cobalt from $9.4 \mathrm{mg} / \mathrm{kg}$ upstream to 695 $\mathrm{mg} / \mathrm{kg}$ downstream. Lithium did not record great increases other than at Tahmoor colliery and the combined discharge of Springvale and Angus Place collieries increasing from below detectable limits to $35 \mathrm{mg} / \mathrm{kg}$ at Tahmoor Colliery and below laboratory detectable limits to $29.6 \mathrm{mg} / \mathrm{kg}$ at Springvale and Angus Place Collieries.

Although large increases were not recorded lithium was only measured in laboratory detectable limits $[<0.5 \mathrm{mg} / \mathrm{kg}]$ at two upstream sites and both at very low concentrations [Springvale Colliery $1.83 \mathrm{mg} / \mathrm{kg}$ and Westcliff Colliery 3.5 $\mathrm{mg} / \mathrm{kg}$. Magnesium recorded the greatest concentrations per $\mathrm{mg} / \mathrm{kg}$ of all the pollutants measures, increasing at six of the eight downstream locations between 75 times and 165 times. Of greatest concern is Berrima [Medway] Colliery which recorded sediment increases downstream of the wastewater inflow some 165 times that of reference sediment manganese. Springvale Colliery is also of concern recording upstream sediment manganese of $15 \mathrm{mg} / \mathrm{kg}$ increasing 160 times to $2425 \mathrm{mg} / \mathrm{kg}$ along with Clarence Colliery which recorded increases in sediment concentrations in the range of 130 times that of reference conditions $[48.76 \mathrm{mg} / \mathrm{kg}$ to 6520 $\mathrm{mg} / \mathrm{kg}$. Both Springvale and Angus Place Collieries individual wastewater discharges recorded increases greater than 30 times at Springvale Colliery [upstream $416.7 \mathrm{mg} / \mathrm{kg}$ and downstream $13300 \mathrm{mg} / \mathrm{kg}$ ] and nearly 25 times greater downstream of Angus Place Colliery [90.2 mg/kg increasing downstream to $2233.3 \mathrm{mg} / \mathrm{kg}$ ]. Strontium recorded increases downstream of six of the eight wastewater discharges with one of the remaining two recording no difference [Below laboratory detectable limits upstream and downstream]. Strontium increased from double to 24 times each waterways respective reference condition.

\section{Conclusions}

Results from this study shows that the coal mine waste water pollutants are accumulating within river sediments downstream of the coal mine waste water inflows at varying levels often greater than the ANZECC guidelines for sediment and often above reference condition sediment concentrations. This is of great concern as these pollutants will likely continue to persist in the river sediment and eventually become legacy pollutants. Of greatest concern are the levels of Nickel and Zinc in relation to the ANZECC guidelines with four downstream locations recording Zinc levels greater than the recommended levels and three locations for Nickel. Magnesium and strontium were also found the be of concern as they increased statistically significantly downstream of most mines and in large concentrations at times.

It appears water column pollution regulation at these coal mines is in fact failing to protect the environment whilst still regulated and will continue into the future post mining, licensing and regulation. Water column regulation may well be impractical in protecting the environment as it appears that water column concentrations do not portray the overall environmental impact. It is recommended that the New South Wales Environmental Protection Authority investigate these findings and continue to improve water column pollutant limits as to alleviate the continued accumulation and magnification of the contaminants.

\section{Acknowledgements}

We acknowledge and pay our respects to the traditional custodians of the land in which this study was conducted. The Dharug, Gundungurra, Tharawal, Wiradjuri and Yuin people and their elder's past and present. This research is a part of the lead authors [Nakia Belmer] PhD candidature and was supported through an Australian Government Research Training Program Scholarship. Thanks to Alison Ellis for the preparation of the study area map. Western Sydney University, the Blue Mountains Conservation Society, Sustainable Southern Highlands and the Colong Foundation for Wilderness all provided funding for chemical analysis of water samples. Envirolab [Sydney] generously provided additional testing. We also acknowledge the energetic field work assistance of Nicholas Szafraniec, Ben Green and Paul Hammond.

\section{References}

[1] Jarvis, A, P, and P, L, Younger, 1997, Dominating chemical factors in mine water induced impoverishment of the invertebrate fauna of two streams in the Durham Coalfield, UK, Chemistry and Ecology, vol 13, pp 249-270.

[2] Johnson, D, B, 2003, Chemical and microbiological characteristics of mineral spoils and drainage waters at abandoned coal and metal mines, Water, Air, and Soil Pollution, vol 3, pp 47-66.

[3] Pond, G, J, Passmore, M, E, Borsuk, F, A, Reynolds, L, and C, J, Rose, 2008, Downstream effects of mountaintop coal mining: comparing biological conditions Using family - and genus-level macroinvertebrate bioassessment tools, Journal of the North American Benthological Society, 27: 717-737.

[4] Younger, P, L, 2004, Environmental impacts of coal mining and associated wastes: a geochemical perspective, Geological Society, London, Special Publication, 236: 169-209.

[5] Wright, I, A, and S, Burgin, 2009, Comparison of sewage and coal-mine wastes on stream macroinvertebrates within an otherwise clean upland catchment, south-eastern Australia, Water, Air and Soil Pollution, 204: 227-241.

[6] Wright, I, A, Wright S, A, Graham, K, and S, Burgin, 2011, Environmental protection and management: a water pollution case study within the Greater Blue Mountains World Heritage Area, Land Use Policy, 28: 353-360.

[7] Belmer, N, Tippler, C, Davies, P, J, and I, A, Wright, 2014, Impact of a coal mine waste discharge on water quality and aquatic ecosystems in the Blue Mountains World Heritage Area, in Viets, G, Rutherfurd, I, D, and Hughes, R, (editors], Proceedings of the 7th Australian Stream Management Conference, Townsville, Queensland, Pages 385-391. 
[8] Wright, I, A, Belmer, N, Price, P, and B, McCarthy, 2015, Subsidence from an underground coal mine and mine wastewater discharge causing water pollution and degradation of aquatic ecosystems, Water, Air and Soil Pollution, 226: 236-348.

[9] Wright, I, A, and M, Ryan, 2016, Impact of mining and industrial pollution on stream macroinvertebrates: importance of taxonomic resolution, water geochemistry and EPT indices for impact detection, Hydrobiologia, 772: 103-115.

[10] Price, P and I, A, Wright, 2016, Water Quality Impact from the Discharge of Coal Mine Wastes to Receiving Streams: Comparison of Impacts from an Active Mine with a Closed Mine, Water Air Soil Pollution 227: 155.

[11] Allen, H, E, Perdue, E, M, and D, S, Brown 1993, Metals in Groundwater, Lewis Publishers, Pp, 437.

[12] Neff, J, M, 1984, Bioaccumulation of organic micro pollutants from sediments and suspended particulates by aquatic animals, Fresenius' Zeitschrift für analytische Chemie, Vol 319, 2, pp 132-136.

[13] Wang, X, W, and P, S, Rainbow, 2008, Comparative approaches to understand metal bioaccumulation in aquatic animals, Comparative Biochemistry and Physiology Part C: Toxicology \& Pharmacology, vol 148, 4, pp, 315-323.

[14] Kolaříková, K, Stuchlík, E, Liška, M, Horecký, J, Tátosová, J, Hardekopf, D, Lapšanská, N, Hořická, Z, Hovorka, J, Mihaljevič, M, Fuksa, J, K, and W, Von Tümplingm, 2012, Long-Term Changes in the Bioaccumulation of $\mathrm{As}, \mathrm{Cd}, \mathrm{Pb}$, and $\mathrm{Hg}$ in Macroinvertebrates from the Elbe River (Czech Republic], Water Air Soil Pollution, vol 223, pp, 3511-3526, DOI 10.1007/s11270-012-1129-1.

[15] Cohen, D, J, McQuade, C, V, Riley, S, J, and S, Adeloju, 1998, Sampling surficial sediments of a river receiving mine water discharges, Coal Operator's Conference, University of Wollongong, Faculty of Engineering and Information Sciences.

[16] Cohen, D, 2005, 'Best Practice Mine Water Management at a Coal Mining Operation in the Blue Mountains', Master of Engineering Honours thesis, University of Western Sydney Nepean.

[17] New South Wales Office of Environment and Heritage, 2015, Clarence Colliery Discharge Investigation,

$<$ http://www.epa.nsw.gov.au/resources/licensing/150171clarence-colliery-discharge-investigation.pdf $>$.

[18] Twining, J, Creighton, N, Hollins, S, and R, Szymczak, 2008, 'Probabilistic Risk Assessment and Risk Mapping of Sediment Metals in Sydney Harbour Embayments', Human and Ecological Risk Assessment: An International Journal, vol, 14, no, 6, pp, $1202-1225$.
[19] Ashraf, M, A, Maah, M, J, and I, Yusoff, 2011, Bioaccumulation of Heavy Metals in Fish Species Collected from Former Tin Mining Catchment, International Journal of Environmental Research, vol 6, 1, pp 209-218.

[20] Goldbery, R, 1969, Geology of the Western Blue Mountains, Geological survey of New South Wales, Bulletin no 20, Department of Mines.

[21] Goldbery, R and F, C, Loughlan, 1977, Dawsonite, alumohydrocalcite, nordstrandite and gorceixite in Permian marine strata of the Sydney Basin, Australia, Sedimentology, $24,565-579$.

[22] Ward, C, R, 1989, Minerals in Bitumous coals of Sydney Basin (Australia] and the Illinois basin (U.S.A], International Journal of Coal Geology 13 1-4 455 - 479, DOI: 10.1016/0166-5162 (89]90104-3.

[23] Brake, S, S, Connors, K, A, and S, B, Romberger, 2001, A river runs through it: impact of acid mine drainage on the geochemistry of West Little Sugar Creek pre- and postreclamation at the Green Valley coal mine, Indiana, USA, Environmental Geology, 1471-1481.

[24] Petty, J, T, Fulton, J, B, Strager, M, P, Merovich, G, T, Stiles, J, M, and P, F, Ziemkiewicz, 2010, Landscape indicators and thresholds of stream ecological impairment in an intensively mined Appalachian watershed, Journal of the North American Benthological Society, 29: 1292-1309.

[25] Victorian EPA, 2009, SAMPLING AND ANALYSIS OF WATERS, WASTEWATERS, SOILS AND WASTES, viewed May 2017, $<$ http://www.epa.vic.gov.au/ /media/Publications/IWRG701.p df $>$.

[26] Li, J and P, B, Tchounwou, 2014, Risk Assessment of Heavy Metals in Surface Sediments from the Yanghe River, China, International Journal of Environemntal Research and Public Health, vol 11, pp, $12441-12453$.

[27] Pavlowsky, R, T, Lecce, S, A, Owen, M, R and D, J, Martin, 2017, Legacy sediment, lean, and zinc storage in channel and floodplain deposits of the Big Z River, Old Lead Belt Mining District, Missouri, USA, Geomorphology, Elselvier, 229, pp $54-75$.

[28] ANZECC (Australian and New Zealand Environment and Conservation Council] and ARMCANZ (Agriculture and Resource Management Council of Australia and New Zealand], 2000, Australian and New Zealand guidelines for fresh and marine waters, National Water Quality Management Strategy Paper No, 4, Australian and New Zealand Environment and Conservation Council/ Agriculture and Resource Management Council of Australia and New Zealand, Canberra. 